The Discovery of Things 



\section{The Discovery of Things}

A R IS TOTLE'S CATEGORIES

A N D T H E I R C O N T EXT

Wolfgang-Rainer Mann

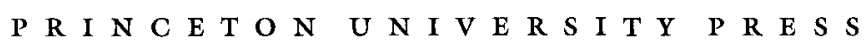

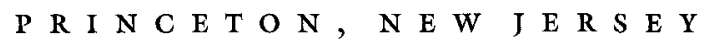


Copyright $(2000$ by Princeton University Press Published by Princeton University Press, 41 William Street, Princeton, New Jersey 08540 In the United Kingdom: Princeton University Press, Chichester, West Sussex All Rights Reserved

Library of Congress Cataloging-in-Publication Data Mann, Wolfgang-Rainer. The discovery of things : Aristotle's Categories and their context / Wolfgang-Rainer Mann. p. $\mathrm{cm}$. Includes bibliographical references (p. ) and indexes. ISBN 0-691-01020-X (cl. : alk. paper)

1. Aristotle. Categoriae. 2. Categories (Philosophy)-History. I. Title. B438.M36 $2000 \quad 160-\mathrm{dc} 21 \quad 99-37823$ CIP

This book has been composed in Galliard The paper used in this publication meets the minimum requirements of ANSI/NISO Z39.48-1992 (R 1997) (Permanence of Paper) http://pup.princeton.edu

Printed in the United States of America 
FOR MY MOTHER AND FATHER,

SIGRID AND JOSEPH MANN 
